\title{
Birinci Dünya Savaşı'nda Osmanlı Jeopolitiğinin Rolü
}

\author{
Role of the Ottoman Geopolitics During the First World \\ War
}

\author{
Burak Çınar*
}

\begin{abstract}
Özet
Osmanlı Imparatorluğu 1914'te Avrupa'da patlak veren savaşı, coğrafi konumu sayesinde üç kıta politikasını etkileyecek şekilde genişletme potansiyeline sahipti. Almanya savaşı sürdürebilmek için Itilaf Devletleri'nin çevrelemesinden kurtulmalıdı ve bunun çaresini de Osmanlı jeopolitiğinden azami surette yararlanmada bulmuştu. Almanlar Osmanlıları kullanmayı başardılar. Osmanlı Imparatorluğu'nun savaşa girişi sayesinde savaş yayllinca, Almanya Avrupa'da nefes aldt. Yeni ortaya çıkan cepheler sayesinde Osmanlı birlikleri çok sayıda Rus ve Ingiliz Koloni tümenini kendi üstüne çekmişti. Ingiliz tümenlerinin Mısır'da birikmesi, Gelibolu, Filistin ve Irak'ta açılan cephelerin takviyesi ve Ruslar için ikinci cephe açılması Osmanlı sayesinde olmuştur. Bu da Almanlara stratejik avantaj sağlamıştır. Ittilaf Gǚcleri de Almanya'yı yenilgive uğratabilmek için çevrelemeyi tamamlamanın Osmanlı'yı savaş dışı bırakmaktan geçtiğini anlamışlardı. Böylece Ingilizler cephe sayısının çokluğuna rağmen Osmanlı'ya yüklendiler. Bu hamle savaşın sonunda Ortadoğu haritasııı tamamen değiştirecekti.
\end{abstract}

Anahtar Kelimeler: Osmanlı Jeopolitiği, Birinci Dünya Savaşı, Almanya, Merkez Güçler, Osmanlı Cepheleri.

\begin{abstract}
Ottoman Empire had the potential to influence policy on three continents, to expand the war broken out in Europe in 1914, thanks to its geographical position. To continue the war, Germany had to get rid of containment of the Triple Entente, and found the solution to maximize to benefit from the Ottoman geopolitics. Germans succeeded in driving the Ottomans. When the war spread with the Ottoman Empire's entry into the war, Germany took a breath in Europe. Thanks to the newly emerging fronts Ottoman forces drew many Russian and British Colonial divisions on its own divisions. Accumulation of the British divisions in Egypt; reinforcement of fronts emerged in Gallipoli, Palestine and Iraq; and opening a second front to Russia was by courtesy of the Ottomans. This was providing strategic advantage to the Germans. And the Entente powers saw German defeat completing the containment after the Ottoman Empire out of war. Thus the British took on the Ottomans despite numerous fronts. This blow would change the Middle East map.
\end{abstract}

Key words: Ottoman Geopolitics, First World War, Germany, Central Powers, Ottoman Fronts.

Yrd. Doç. Dr, Niğde Üniversitesi, İktisadi Ve İdari Bilimler Fakültesi, Siyaset Bilimi Ve Uluslararası İlişkiler Bölümü. E-mail: burakcinar@ttmail.com

Akademik Bakış 39 Cilt 8 Sayı 15 Kış 2014 


\section{Giriş}

Birinci Dünya Savaşı Saraybosna Suikastı'nın arkasından, Avusturya-Macaristan İmparatorluğu'nun diplomatik baskıları ve Sırbistan'ın buna direnç göstermesi doğrultusunda Avrupa'daki iki ittifakın çatışmasının savaşa dönüşmesiyle ortaya çıkmıştı. Almanya ve Avusturya-Macaristan bloğunun karşısında Britanya, Fransa ve Rusya'dan oluşan daha kuvvetli bir blok mevcuttu. 28 Temmuz 1914'te Avusturya-Macaristan birliklerinin Sırbistan'a harekât başlatmasıyla patlak veren savaş, kısa sürede karşılıklı savaş ilanlarıyla bu iki blok sayesinde tüm Avrupa'yı sarmıştı.

Britanya ve Fransa'nın sömürgeleri göz önünde bulundurulduğunda, İtilaf devletlerinin gücü Merkez Güçler'e asimetrik ölçüde fazlayken, Avrupa'da ise Almanya'nın askeri gücünün ağırlığı söz konusuydu. Bu arada Almanya'nın hiç istemediği bir şekilde, Fransa ve Rusya arasında "iki cepheli savaş" ortaya çıkmıştı. Ayrıca, Merkez Güçler Avrupa'nın ortasında çevrelenmiş görünüyordu. İngilizlerin denizden abluka stratejisi de en baştan beri yürürlülüğe konmuş ve Almanya'nın sömürgeleriyle bağlantısı kesilmişti. Bu durumda Almanya için ancak savaşın yayılması bir çıkar yol olabilirdi. Bunun için de acilen Avrupa haritasının bir kenarında konuşlanmış müttefik ihtiyacı vardı. Haritaya bakıldığında, Avrupa'nın güneydoğu ucundaki Osmanlı İmparatorluğu, savaşı Avrupa'dan Asya ve Afrika'ya taşıyabilecek tek coğrafya olarak göze çarpıyordu.

Bu araştırmada Osmanlı İmparatorluğu'nun jeopolitiğinin Almanya için nasıl kullanıldığı incelenmektedir. Bu doğrultuda gelişen askeri ve siyasi olaylar birlikte incelenecek ve analiz edilecektir. Araştırmanın ilk bölümünde Birinci Dünya Savaşı'nda savaş ve jeopolitik disiplininin gelişimi arasında ilişki kullanılacak, jeopolitiğin Avrupa'daki savaş için ne anlam ifade ettiğine yer verilerek, Alman-Osmanlı ittifakının kurulmasıyla ilişkilendirilecektir. Ardından Osmanlı İmparatorluğu'nun savaşa girişiyle, savaşın doğuya genişlemesinin getirdikleri Osmanlı jeopolitiği ve bunun Almanya açısından önemi verilecek

Akademik

Bakış

ve sonuca etkisi açısından Osmanlı cephelerinin özellikleri incelenecektir. Diğer bölümde ise Osmanlı coğrafyasına bağlı olarak olayların gelişimi analiz edilerek, araştırma sonuca bağlanacaktır.

\section{Birinci Dünya Savaşı İçin Savaş, Siyaset ve Coğrafya}

Birinci Dünya Savaşı, "savaşın politikanın başka araçlarla uzantısı olduğu" düşüncesi üzerinde gelişen Clausewitz ekolünün biriken etkisinin diş politika gündeminde devam ettiği bir dönemde ortaya çıkmıştır. Bu dönemin son aşamasında güç politikası uygulayan devletlerin karşılıklı ittifaklaşmayla sürdürdükleri güç dengesinin savaşı önleyeceği yanılgısı, 1914 Temmuzu biterken sona erdi. Bu ikisi, 19. yüzyıl Avrupa siyasetinin önemli araçları olarak görülürken, yüzyılın sonlarına doğru "dünya hâkimiyeti" çerçevesinde şekillenen jeopolitik teorilerin ortaya çıkmaya başlaması ise dünya siyasetine yeni bir araç daha kazandırmıştı. 


\section{Ülkelerin Lisant Olarak Jeopolitik}

Bir ulusun kuvvetine temel teşkil eden en istikrarlı faktör o ülkenin coğrafyası olmuştur. ' Jeopolitik ise en basit tarifiyle coğrafyanın siyasi olarak yorumu olarak göze çarpmaktadır. ${ }^{2}$ Jeopolitiğin bir disiplin olması, Birinci Dünya Savaşı'ndan bir kuşak öncesine rastlar. Bu dönemde yapılan ve Jeopolitiğin klasik teorilerinin temelini oluşturan Mackinder'in "Kara Hâkimiyeti" ve Mahan'ın "Deniz Hâkimiyeti" teorileri günümüzde hâlâ çatışmaktadır. Bu iki teorinin çatışma alanı ise aslında Mackinder'in "iç hilal" olarak altını çizdiği ve iki kez revize ettiği, sonradan da Spykman'a "kenar kuşak" olarak ilham veren ve geniş Rus steplerini güneyden saran, Avrasya boyunca uzanan kuşaktır. Osmanlı İmparatorluğu, savaş öncesinde kuzeyden güneye uzantısı sayesinde, Mackinder'in sonradan revize ettiği haliyle birlikte "iç hilal-diş hilal" geçişini sağlayan bir alanda kuruluydu. Dış hilal, iç hilalin de dışında kalmaktadır ve burası "Deniz Hâkimiyeti” teorisi doğrultusunda deniz gücüne verdikleri öncelik sayesinde 19. ya da 20. yüzyıllarda birinci güç olan Britanya İmparatorluğu ve ABD gibi ülkelerin nüfuz alanları olmuştur. Savaş öncesinde dış hilal sömürgelerin toplandığı bölgeydi ve bu sömürgelerin büyük çoğunluğu Britanya'ya ya da Fransa'ya aitti. Almanya, Avusturya ve Osmanlı hep birlikte iç hilal denen çatışma bölgesi üzerindeydiler. Almanya için Osmanlı jeopolitiği, çatışma bölgesinden sömürgelere çıkış anlamını taşıyordu. ${ }^{3}$

Ülkelerin bulundukları konum, kara ya da deniz ülkesi olmaları, bu özelliklerinin savunma yapılanmalarına ve dış politikalarına etkileri, barışta ve savaşta benzer ya da farklı şekillerde kullanabilecekleri gücün önemli bir kısmını oluşturmaktadır. Bununla birlikte, ülkelerin endüstri bölgelerinin ve başkentlerinin stratejik derinlikleri de savaş sırasında harekâtlara imkân vermeleri açısından bu gücü artıran ya da azaltan önemli bir etmendir.

\section{Alman-Osmanlı Ittifakının Jeopolitik Okunması}

Bu bölümde Alman-Osmanlı ittifakının kurulmasının iki ülke için ne anlama geldiği üzerinde ayrıca durmak faydalı olabilir. Öncelikle bir ittifakın kurulabilmesi için en az iki ülkenin "ortak çıkarları" doğrultusunda bir araya geldiği bilinmektedir. Bununla birlikte, "karşı taraf" riskini benzer biçimde algılamayı

1 Hans J. Morgenthau, Uluslararası Politika Cilt.I, (çev:Baskın Oran ve Ünsal Oskay), Türk Siyasi İlimler Derneği Yayınları, Ankara 1970, s.141.

2 Yılmaz Tezkan v.d., Dünden Bugüne Jeopolitik, Ülke Kitapları, İstanbul 2002, s.15.

3 Mackinder'in "kalpgâh" olarak nitelediği ve iç hilalin çevrelediği alanın büyük kısmı ise savaşa girilirken Rus İmparatorluğu'na aitti. Mackinder'in Kara Hâkimiyeti Teorisi'ndeki iddiası “kalpgâha sahip olanın dünya hâkim olacağı yönündeydi. Ancak sonradan Soğuk Savaş dönemi olayları bize bu hâkimiyetin, Deniz Hâkimiyeti Teorisi ile arasındaki çatışma alanı olan kenar kuşağın (iç hilalin) kazanılmasına bağlı olduğunu göstermiştir. Nitekim iç hilali "kenar kuşak" olarak adlandıran Spykman'ın 1942'de geliştirdiği Kenar Kuşak Teorisi, Amerikan Dış Politikası'nda Soğuk Savaş sırasında Sovyetler Birliği'ne uyguladığı "Çevreleme Politikası" için bir teorik altyapı olmuş ve başarı kazanmıştır. Bkz: A.g.e., s.77, 143.

Akademik Bakış 41 Cilt 8 Sayl 15 Kış 2014 
da gerektirmektedir. ${ }^{4}$ Bu noktada Alman-Osmanlı ittifakının kurulmasında, bu ortak çıkarların ne olduğu tartışmaya açıktır. Yine de Birinci Dünya Savaşı sırasında Osmanlı'nın savaş girişini getiren bu ittifakın öncelikle Rusya'ya karşı olduğunu söyleyebiliriz. Rusya'nın ardından İngiltere ve Fransa gelmektedir. Ancak Fransa Almanya için olduğu şekliyle Osmanlı için tehdit değildi.

Buradan yola çıkarak, Osmanlı'nın savaşa girişini hem İttihat ve Terakki'nin Türk jeopolitiğinin önünü açma girişimi hem de Kuzey Afrika ve Balkanlar'da resmen ya da fiilen yakın zamanda kaybedilen toprakların ardından İngiliz ve Rus tehditlerine karşı bir çıkış yakalayabilmesi için oynadığı bir kumar olarak düşünebiliriz. Bu doğrultuda, Alman ve Osmanlı çıkarlarının uyuştuğu jeopolitik hususlar da savaşta Boğazlar'ın İtilaf Devletleri'ne açık tutulmaması, Süveyş Kanalı'nın ve Doğu Akdeniz'in güvenliğinin sağlanması ve Osmanlı İmparatorluğu'nun İslam dünyasında tekrar nüfuz sahibi olacak biçimde kısmen güçlenmesi olarak düşünülebilir. Nitekim Osmanlı'ya önemli çıkarlar sağlayabilecek bu gelişmeler, Almanya için de ablukanın kırılması anlamına geliyordu.

Osmanlı'nın Almanya'ya bağımlı, bir güç olarak, İslam dünyasında otorite olması Almanya'nın çıkarlarınaydı. Avrupa'da saldırı inisiyatifini elinde bulundurarak, savaşı Fransız ve Rus topraklarına yıkmayı başaran Almanya'nın; Osmanlı'yı doğudan geniş bir taciz üssü yaparak, İngiliz ve Fransız koloni birliklerini Fransa yerine Osmanlı topraklarına çekmeye çalıştığı görülmektedir.

Aslen tarihçi olan ve Fransız-Rus yakınlaşmasını sağlayan eski Fransız Dışişleri Bakanı Gabriel Hanotaux, İtilaf Devletlerinin Balkanlar sorununda Osmanlı aleyhindeki yönelik politikasını eleştirirken, Osmanlı'nın jeopolitik öneminin Almanya'ya sağlayacağı faydalar konusunda önemli uyarılarda bulunmuştu:

“Balkanlar'a da müdahale etmekte devletler (itilaf devletleri) için önemli nedenler vardı, Türkiye onlara karşı durum aldığı zaman, Türkiye'nin iki Alman devlete (Almanya ve Avusturya devletleri)ne sağlayacağı yararlara engel olmak gerekliydi, bu Rusya'ya karşı oluşmuş bir cepheydi, bu Rusya'nın güneyde karadan ve denizden kuşatılmasıydı; bu İngiltere'nin Süveyş kanalında ve Hindistan'da tehdit altına düşmesi idi." ${ }^{5}$

4 Beril Dedeoğlu, Uluslararası Güvenlik Ve Strateji, Yeniyüzyıl Yayınları, İstanbul 2008, s.222.

5 Gustav Le Bon, I. Dünya Savaşı'ndan Alınan Psikolojik Dersler, (çev: Mehmet Demirezer), Ufuk Yayınları, İstanbul 1999, ss.239-240. Hem iç hilalde bulunan üç imparatorluğun ittifak oluşturmasıyla Rusya'nın çevreleneceğini hem de Almanların Osmanlı coğrafyasını kullanarak Süveyş ve Hindistan'ı tehdit edeceğini öngören Hanotaux'un Osmanlı jeopolitiğini iyi okuduğu ortadadır. Nitekim Birinci Dünya Savaşı'nda Hanotaux'un öngördüğü şekilde Merkez Güçler tarafından çevrelenen Rusya 1917 İhtilalinden sonra savaştan ilk çekilen devlet oldu. 


\section{Osmanlı İmparatorluğu'nun Savaşa Girişiyle Savaşın Genişlemesi}

Osmanlı İmparatorluğu'nun savaşa girmesini öncelikle iki cepheli ve çok cepheli savaş kavramlarına bakarak incelemek gerekir. Bunun nedeni Osmanlı'nın, kaynakları Britanya İmparatorluğu ile kıyas edilemeyecek olan Almanya'nın yanında savaşa girmesinin oldukça riskli bir kumar olduğu ve ancak Merkez Güçler'in kazanmasıyla önemli kazanımlar elde edeceği düşüncesinin olduğudur. Buna bağlı olarak, Birinci Dünya Savaşı'nda İngiltere'nin kara savaşı yaşayacağı cephelerin sayısı "Batı" ve "Balkanlar" ile sınırlı olabilecekken, Osmanlı'nın savaşa girmesiyle Batı'nın dışında Ortadoğu'ya odaklanması en önemli gelişmedir. İkinci olarak, Rus İmparatorluğu'nun da aynı şekilde kendi Batı Cephesi'nde (Alman Doğu Cephesi) Alman ve Avusturya-Macaristan ordularıyla savaşırken, Doğu Anadolu ve Kafkaslar'da Osmanlılarla savaşmaya zorlandığını görüyoruz. Bununla birlikte, Osmanlıların Boğazlar'a sahip olması ve İngiliz-Fransız güçlerinin Batı Cephesi lehinde Alman Doğu Cephesi'ni kuvvetlendirmesi için Rusya'ya acil yardım yolunun Boğazlar'dan geçmesi, Osmanlı'nın savaştaki önemini ön plana çıkarmıştır. Osmanlı'nın bu önemi sahip olduğu coğrafyanın kaynaklarından oluşmaktadır ve dolayısıyla Osmanlı jeopolitiğinin Birinci Dünya Savaşı'nda savaşın yayılması açısından çok önemli bir role sahip olduğunu söyleyebiliriz.

\section{Osmanlı Jeopolitiği}

1869'da Süveyş Kanalı'nın açılması Osmanlılar için uzun vadeli bir sorun olmuştu. Bundan sonra Osmanlı'nın Afrika'daki özerk bölgeleri elden çıkmaya başladı. 1881'de Fransızlar Tunus'u, 1882'de ise İngilizler Mısır'ı işgal etmişlerdi. 1912'de Libya da elden çıkınca Osmanlı'nın Afrika'da toprağı kalmayacaktı. Buna karşı İngilizler Sina Yarımadası sayesinde Osmanlı'ya karşı bir köprübaşı elde ettikleri için, olası bir savaşta Ortadoğu'yu tehdit edecek konuma gelmişlerdi. Daha önce üç kıtada topraklara sahip olan Osmanlı coğrafyası, en son Trablusgarp ve Balkan savaşları nedeniyle savaşın arifesinde büyük ölçüde Asya kıtasına indirgenmişti. Buna rağmen, Osmanlı İmparatorluğu İngiliz sömürge ve himaye bölgelerine ulaşmak için Almanya'ya en yakın ülke konumundaydı. Aynı zamanda Rusya'nın İngiltere ile deniz yoluyla bağlantısını sağlayabileceği bir konuma sahipti. Gerçi Almanya ve Osmanlı arasında Balkan ülkeleri ve Avusturya-Macaristan İmparatorluğu olmadan bağlantı kurulamazdı. Ancak Balkanlar'da belli bir bölge işgal ya da ittifak yöntemleriyle elde edilirse, lojistik bağlantı kurulabilirdi.

Osmanlı coğrafyası stratejik savunma yapmasını kolaylaştıracak yeterlikte stratejik derinliğe sahipti. Müttefiklerin de bunu çok iyi değerlendirdikleri ortadaydı. Hatta Irak ve Filistin'de savaşmak yerine Boğazlar'ı zorlama riskini bu nedenle göze aldıklarını söyleyebiliriz. İngilizler harita üzerinde böyle bir 
harekâta girişmek için bir ön teşkil eden jeopolitik düşüncede haklıydılar. Ancak İstanbul'un da Ege-Marmara rotası sayesinde denizden yeterli bir stratejik derinliğe sahip olması ve bu iki denizi birbirine bağlayan kontrol noktası olan Çanakkale Boğazı'nı asimetrik oranda kuvvetli oldukları deniz gücüyle aşabilecekleri düşüncesinde hatalıydılar. Bu yanılgı İngiliz ve Rusların Almanya'yı çevreleme stratejisinin başarıya ulaşması için, Osmanlı İmparatorluğu'nun jeopolitiğini lehlerine çevirmeleri ihtiyacını fark etmeleri sayesinde ortaya çıkmıştır. Dolayısıyla savaş öncesinde Osmanlı'yı ittifakla kazanmayı beceremeyen İtilaf Devletleri, bu diplomatik hatalarını savaş başlayınca askeri bir hatayla gidermeye çalışmışlardır.

\section{Osmanlı Coğrafyasının Alman İmparatorluğu İçin Önemi}

Almanya ne kadar güçlü olursa olsun, Kuzey Avrupa'da sıkışmış bir ülkedir. Alman İmparatorluğu'nun sömürgelere açılma çabasının önünde, en güçlü donanmaya sahip olan Britanya İmparatorluğu'nun savaş zamanında Manş ve Kuzey Denizi'ni kapatmak suretiyle uyguladığı abluka engeli mevcuttur. Bu strateji Kaiser II. Wilhelm ile 1890'larda Weltpolitik uygulamasına geçen Almanların, İngilizlerle olan siyasi ilişkilerinde en önemli dezavantaj olmuştur. Bu doğrultuda, Büyük Amiral Alfred von Tirpitz sayesinde Birinci Dünya Savaşı'nın öncesinde oluşturulan modern Alman Açık Deniz Filosu, askeri bir çözüm düşüncesiyle ortaya çımıştı. Ancak siyasi çözüm için Birinci Dünya Savaşı'nın hemen öncesinde Almanya'nın seçenekleri oldukça sınırlıydı.

Bismarck'tan sonra Almanya'nın doğusundaki Rusya ile ilişkilerindeki başarısızlığı sayesinde savaş öncesinde Fransız-Rus ittifakı İngiltere ile birlikte hazırdı. Fransız-Rus ittifakı Almanya'yı bir savaş sırasında kuvvetli bir iki cepheliliğe götürecek tek seçenekti ve İngiltere'nin de özellikle donanmasıyla buna denizden destek vermesi, Almanya'nın hem iki cepheli savaşa zorlanması hem de çevrelenerek Kuzey Avrupa'ya hapsedilmesi anlamına geliyordu. Avrupa'nın merkezinden Balkanlar'a kayan Avusturya-Macaristan İmparatorluğu ile yaptığı ittifak ise bu ülkenin Adriyatik'te kapalı kalmış ve etkin güce ulaşamamış donanmasıyla ablukayı kıracak bir getirisi yoktu. Sadece İtalya kısıtlı olarak savaş sırasında Almanya'nın dünyaya açılış kapısı olabilirdi. Nitekim Cebelitarık ve Süveyş İngilizlerin denetimindeydi ve Akdeniz'deki Fransız Donanması da kuvvetliydi. Dolayısıyla İtalya'nın deniz gücü de İtilaf Devletleri'nin donanmaları tarafından sınırlanıyordu. Kaldı ki, Almanya ile müttefik görünen İtalya savaşa önce girmeyecek, ardından da İtilaf devletleriyle işbirliği yapacaktı.

Bu durumda Almanya için Avrupa'da çıkış yolu görünmüyordu. Ordusunun örgüt yapısı, mobilizasyon kabiliyeti, lojistik kuvveti, asker ve silah kalitesi ne kadar iyi olursa olsun; bir yandan geniş sömürgelerden güç alan İngiliz ve Fransız birliklerine ve diğer yandan Rusya'nın baskısına uzun süre direnmesi zordu. Ancak 1914 yazında savaş bir anda patlamış, Almanya ve Avusturya; 
İngiltere, Fransa ve Rusya'ya karşı savaşa girmişti. Almanya'nın bu dezavantajdan kurtulması için stratejisini mutlaka Avrupa'nın dışına genişletmesi gerekiyordu.

Bu noktada, yeni açlımlara elverişli politikalar üretebileceği tek bölgenin Osmanlı İmparatorluğu'nun egemenlik alanı olduğu göze çarpmaktadır. Osmanlı İmparatorluğu II. Wilhelm'in Fransız-Rus ittifakını kırabilmesi için tek yoldu. Osmanlı'nın katılımıyla, Merkez Güçler batılı demokrasilerle onların teçhizatına çok fazla ihtiyacı olan Rusya arasındaki tek pratik yol olan Çanakkale Boğazı'nı kapatabilirlerdi. ${ }^{6} \mathrm{Ne}$ de olsa Avrupa'nın uzak bir ucundan başlayarak Asya'ya doğru uzanan Osmanlı coğrafyası Almanya'nın Avrupa'dan çıkış kapısı, Boğazlar da onun menteşeleriydi. Osmanlı coğrafyası Kafkaslar'a, İran'a, Kızıldeniz'e ve Süveyş'in doğusundaki İngiliz köprübaşına sahip Sina Yarımadası'na kadar uzanıyordu. Fransız tarihçi Pierre Renouvin şöyle demiştir: "Almanya'nın Osmanlı Devletinin savaşa katılmasında büyük çıkarları vardı. Fakat bu derhal sonuç veremezdi. Boğazların kapatılması, Rusya'nın buğdayını ihraç etmesine, müttefiklerinden çok gereksinme duyduğu savaş gereçlerini almasına engel olacaktı. Padişahın "kutsal savaş" ilan etmesi, Müslümanların bağnazlığını kamçılayacak... İngiliz sömürgelerine bir parola gönderilecek... Hindistan'da, Mısır'da, Kafkasya'da ayaklanmalara neden olacaktı."

Dolayısıyla savaş Avrupa'dan dişarı geniş bir coğrafyaya Osmanlı ile birlikte yayılabilirdi. Bu durumda Almanya ablukaya batıdan askeri çözümle, doğudan ise siyasi çözümle karşı koyabilirdi. Nihayet Osmanlı İmparatorluğu ile 2 Ağustos 1914'te gizli bir ittifak kurarak, bu siyasetini uygulama fırsatı buldu. ${ }^{8}$ Ancak Almanlar Osmanlı'nın savaşa katılması için Paris hedefli genel saldırının geçmesini beklemişlerdi. Alman birliklerinin Marne'de, Avusturya-Macaristan birliklerinin de Galiçya'da aldıkları erken yenilgiler, Osmanlı'nın savaşa sokulmasını gerektirmiştir. Merkez Güçler Rus kuvvetlerinin bir kısmının Kafkaslar'a nakledilmesi ve İngiltere'nin de Mısır'ı korumaya mecbur edilmesi için 17 Eylül 1914'ten itibaren İstanbul'daki Alman büyükelçisi aracılığıyla Osmanlı'nın savaşa girmesi için çalışmaları hızlandırdı. ${ }^{9}$

6 S.L.A. Marshall, The American Heritage of World War I, American Heritage/Bonanza Books, New York 1982, s.69.

7 Pierre Renouvin, 1. Dünya Savaşı 1914-1918, (çev: Adnan Cemgil), Altın Kitaplar, 3. Baskı, İstanbul 1982, s. 209.

8 Savaş başlarken Osmanlı İmparatorluğu ile Almanya arasında karasal bir bağ yoktu. Osmanlı'nın savaşa girerek Alman desteğiyle uzun süre dayanması ve hatta taarruz kabiliyetini yükseltmesi için Berlin-İstanbul demiryolunun güvenliğinin sağlanması gerekiyordu. Ancak demiryolu Sırp ve Bulgar topraklarından da geçtiği için hem Avusturya-Macaristan birliklerinin Sırbistan'ı işgal etmesi hem de Bulgaristan'ın Bağlaşık devletlere katılması gerekiyordu. Bunların gerçekleşmesi, yani Alman-Osmanlı lojistik hattının güven altına alınması 1915'in sonlarını bulmuştur.

9 A.g.e., s.209. 


\section{Osmanlı Cephelerinin Özellikleri}

Osmanlı İmparatorluğu'nun jeopolitik konumunu inceledikten sonra, buna bağlı olarak açılan yeni cephelerin özelliklerini tartışmak yararlı olabilir. Bunlar Çanakkale, Doğu Anadolu (Kafkas), Irak ve Filistin cepheleridir. Ayrıca Hicaz, Asir ve Yemen gibi daha küçük cepheler de açılmış ve sömürgeleri ayaklandırma düşüncesiyle Alman-Osmanlı sızma faaliyetleri de düşünülmüştü.

\section{Çanakkale-Gelibolu Cephesi}

Osmanlı'nın en önemli jeopolitik özelliklerinden biri Boğazlar'dı. Boğazlar gibi geçiş bölgelerine sahip olan devletler buraya ilişkin dış taleplerini güvenlik anlayışına dâhil ederek, buraların kontrolünü ulusal güvenlik meselesi haline getirebilmektedirler. ${ }^{10}$ Boğazların kontrolü meselesi 18. yüzyıldan beri gelişen Rus algılamasında, Rusya'nın denizaşırı sömürgelere açılmasını engelleyen en önemli unsur olarak görülmüş ve özellikle 19. yüzyılda Osmanlı'nın lehine ve aleyhine olan Rus girişimlerinin Osmanlı için riskten tehdide dönüşmesinde önemli rol oynamıştı. Birinci Dünya Savaşı başlamak üzereyken, Rusya'nın bir Osmanlı saldırısına olumlu baktığı izlenimi hiç de şaşırtıcı değildir. Nitekim Birinci Dünya Savaşı'na yaklaşlırken, 1904-1905 Rus-Japon Savaşı'nda Boğazlar'ın Rus savaş gemilerine kapanması, Rus Karadeniz Donanmasının savaş dışı kalmasına neden olmuş, Trablusgarp Savaşı'nda Boğazlar'ın ticari gemilere kapanması ise Rusya'ya ayda 20 milyon rublelik bir kayba mal olmuştu. ${ }^{11}$

Yeni bir savaşta Rusya'nın eline Boğazlar'a kesin hâkim olma fırsatı geçebilirdi. Osmanlı ile savaşlarında yaşadığı 150 yıllık dönemde, Rusya Boğazlar’a adım adım yaşamayı başarmıştı. Bu nedenle ne Göben muharebe kruvazörü ve Breslau kruvazörünün Osmanlı himayesine girişine ne de Boğazlar'ın kapatılmasına ses çıkarmıştı. Dolayısıyla Rus Dışişleri Bakanı Sergei Dmitrievich Sazonov'un İstanbul'daki Büyükelçisi Mikhail Nikolayevich von Giers'e 10 Ağustos'ta çektiği telgrafta, “Osmanlı'nın Rusya'ya karşı girişeceği işlerden korkularının olmadığını" belirtmesi anlamlıdır. ${ }^{12}$ Belki de Sazonov İngiltere he-

Akademik nüz harekete geçmeden Boğazlar'ı ele geçirerek, elinde tutmayı hayal ediyordu. Ancak Rus Ordusu Genelkurmay Başkanı Grandük Nikolay Nikolayeviç'in Boğazların alınabileceğine ya da elde tutulabileceğine yönelik inancı yoktu ve Çar başkomutanlık görevini kendi üstüne aldıktan sonra kurmay başkanı olan M. V. Alekseev Boğazlar'ı ele geçirme düşüncesinin bir yanılsama olduğunu düşünüyordu. ${ }^{13}$ Demek ki, Osmanlı coğrafyasının zorlukları Rus askeri ve siyasi

10 Beril Dedeoğlu, Uluslararası Güvenlik Ve Strateji, Yeniyüzyıl Yayınları, İstanbul 2008, s.48

11 William J. Fuller, "Doğu Cephesi”, Jay Winter vd. der., I. Dünya Savaşı Ve 20. Yüzyıll, (çev: Tansel Demirel), Türkiye İş Bankası Kültür Yayınları, İstanbul 2012, s.35.

12 Pierre Renouvin, 1. Dünya Savaşı 1914-1918, (çev: Adnan Cemgil), Altın Kitaplar, 3. Baskı, 1982 S.210.

13 William J. Fuller, "Doğu Cephesi”, Jay Winter vd. der., I. Dünya Savaşı Ve 20. Yüzyıl, (çev: Tansel Demirel), Türkiye İş Bankası Kültür Yayınları, İstanbul 2012, s.65. 
otoritelerinde gerçekçi olup, olmamaktan ileri gelen bir zıtlık yaratmıştı. Ancak 1914 Ağustos'unda Rusların önemli bir mecburiyeti vardı ki, o da savaşa girdiği Alman ve Avusturya-Macaristan ordularından her an bir saldırı gelebileceği gerçeğiydi. Dolayısıyla Rusya'nın asli cephesi Batı Cephesi (Almanların Doğu Cephesi) olmuş, Kafkaslar'da Osmanlı'ya karşı savunma için bırakılan belli bir kuvvetin haricinde Batı'ya odaklanılmıştı. ${ }^{14}$ Nikolayeviç 1914-1915 kışında Sarıkamış'ta yaşanan kilitlenmeye bağlı olarak, İngilizlerden Osmanlılara karşı Türkleri Kafkas Cephesi'nden uzak tutacak bir faaliyet istemişti. ${ }^{15}$ Bunun üzerine Çanakkale Deniz Harekâtı'nın tartışılması ve planlanmasına başlandı.

Osmanlı Ordusu burada hem Çanakkale Boğazı boyunca denizde hem de çıkartma bölgeleri olarak, karada stratejik savunma inisiyatifine sahip olduğu için avantajlı konumdaydı. Bununla birlikte, İstanbul'a yakınlığıyla bilinen Çanakkale Boğazı başkentin dış kale kapısı gibiydi. Yani Çanakkale Boğazı'nın geçilmesi, kısa vadede Osmanlı'ya, uzun vadede Almanya'ya karşı stratejik sonuç alınması için önemliydi. Konvansiyonel silahların kullanıldı̆̆ı savaşlarda stratejik sonuca erken ulaşılabilir bir durum belirirse, bunun için oynanacak kumar -bedeli ne olursa olsun- verimli bir girişimdir. Osmanlı için İstanbul'un ötesinde bir stratejik derinlik düşüncesinden, TBMM'nin kurulduğu Ankara'nın geliştiği 1920'ye kadar söz etmek mümkün görünmemektedir. Zaten İtilaf Devletleri için asıl olan, Osmanlı'yı bir darbede resmen ya da fiilen savaş dışına itebilmekti.

Böyle bir zafer sonucunda öncelikle üç stratejik sonuç ortaya çıkabilirdi. İlk olarak Osmanlı merkezden sarsılır ve savaştan çekilebilirdi. Savaştan çekilmese bile Anadolu-Irak-Filistin üçgeninde Alman yardımından uzak bir şekilde çevrelenerek mevcut lojistik gücü sonuçlanana kadar mücadele edebilirdi. Karadeniz, Ege ve Akdeniz üslerinin tamamen düşman işgaline uğrayacağı düşüncesiyle, bu mücadele karasal olurdu. Irak Cephesi'nin akıbetine bağlı olarak da İran üzerinden bazı bölgelere ve dünyaya cılız bir açılma ihtimali baki kalırdı. Trakya toprakları ise kaderine terk edilirdi. Dolayısıyla İstanbul'un düşmesi Osmanlı'nın çöküşü olarak görülmektedir.

İkinci olarak, İtilaf Devletleri bu sayede Rusya'ya sevkiyat rotasını en kısa yoldan ve güvenli bir şekilde sağlamış olurdu. Bu da kuvvetle muhtemel, hem

14 Rusya büyük bir Alman saldırısı beklediği için Batı'ya odaklanmıştı ve bu nedenle Osmanlı savaşa girmeden önce Kafkas Cephesi'nde Osmanlı Ordusu'nun Rus Ordusu'na 2:1 gibi bir üstünlüğü söz konusuydu. Bkz: A.g.e., s.65. Osmanlı İmparatorluğu Rusya'ya denizden hücum ederek belki de büyük bir sürpriz fırsatını kaçırmıştı. Eşgüdümlü olarak karadan da harekâta başlatılmış olsaydı, savaş alanını doğrudan Rus topraklarına yıkan bir avantajın getireceği üstünlükten yararlanma ihtimali vardı. Tabi, bu dönemde Osmanlı Ordusu'nun hazırlığının yetersizliğinden ve bölgede coğrafyasının lojistik hatları nasıl zorladığından da bahsedilebilir. Bununla birlikte, hazırlılığın ve lojistik yetersizliğin her iki tarafta da bulunduğu şartlarda saldırı inisiyatifine sahip olanın avantajlı olduğu da Rommel'in İkinci Dünya Savaşı'nda Kuzey Afrika'daki harekâtlarında su yüzüne çıkmıştır.

15 Martin Gilbert, First World War, Henry Holt, New York 1994, s. 121. 
Alman Doğu Cephesi'nde hem de Osmanlı Doğu Cephesi'nde dengeyi bozacak gelişmelere yol açabilirdi. Dolayısıyla Almanya'nın Doğu ve Batı cephelerinden sıkıştırılması düşüncesi, 1915'te Çanakkale'den gelecek başarıya bağlanmıştı.

Son olarak, İngiliz kolonilerindeki halkı ayaklandırmaya yönelik özel harekât kapsamındaki istihbarat faaliyetleri için de Osmanlı üs konumundan çıkardı. Bu da buralardaki birliklerin bir kısmının daha Avrupa'daki cephelere sevk edilmesi demekti.

\section{Doğu Anadolu Ve Kafkas Cepheleri}

Osmanlı İmparatorluğu'nun savaşa girişiyle, üç Merkez Gücün Rusya'yı çevrelemesi Baltık'tan başlıyor ve Kafkaslar'a kadar uzanmış oluyordu. Osmanlı Donanması'nın Karadeniz'deki Rus limanlarına yaptığı baskınlar sonucu Rusya ile savaşa girmesi, iki ülkenin karşılaşabileceği tek cephe olan Kafkas Cephesi'ni hareketlendirmişti. 1914 kışı kapıdayken, Rus Ordusu hızlı bir harekâtla sınırdan Erzurum istikametinde sokulmaya başlayınca, Osmanlı Ordusu Rus Ordusu'nu karşılamış ve Köprüköy ve Azap muharebelerinde gelen galibiyetlerle karşı saldırı fırsatı yakalamıştı. Bunun üzerine Osmanlıların başlattığı Sarıkamış Saldırı Harekâtı, cephede stratejik sonuç almaya yönelik bir girişimdi ve jeopolitik açıdan Rusya'nın çevrelenmesini, Kafkaslar boyunca Hazar Denizi'ne kadar uzatmayı hedefliyordu. Bu sayede Kuzey Kafkasya, Hazar ve Kuzey İran'daki Müslüman Türkler üzerinde etki yaratılabilir ve Britanya'nın İran üzerinden Rusya'ya ulaşımı engellenebilirdi. Almanların Tannenberg galibiyetinin ardından, Rusların Sarıkamış'ta da mağlup edilerek coğrafi açıdan dezavantajlı konuma gelmesi ve Britanya ile arasında Baltık, Boğazlar ve İran üzerinden hızlı ulaşım bağlarının tamamen kesilmesi, Rusya'yı erken bir barışa mecbur edebilecek şartları oluşturacaktı. Rusya'ya karşı savaş kazanılsa, hem Almanya'nın Doğu Cephesi hem de Osmanlı'nın Doğu Cephesi kapanır ve buraya yönlendirilen kaynaklar başka cephelere aktarılabilirdi. Rusya direnmeyi sürdürse bile en kötü ihtimalle Kafkaslar'daki cephe sabitlenmiş olacaktı ki, bu da Rusya'yı iki cephede saldırı inisiyatifinden mahrum bir savaşa zorlardı. Böyle bir durumda Rusya Fransa'dan gelecek müjdeli haberi bekleyecekti.

Ancak 1915 Ocak'ına girildiğinde Rusya Kafkas Cephesi'nde saldırı inisiyatifini ele geçirerek; Trabzon, Erzincan, Muş, Bitlis ve Van gibi şehirleri işgal etti. Bunu cephedeki karşılıklı harekâtlar ve Ermeni faaliyetleri izledi. Rusya'nın Osmanlı'nın Doğu Cephesi'nde Doğu Anadolu'yu geçememesi ise hem bölgedeki dağlık coğrafyanın savunmaya elverişli olması ve lojistik faaliyetleri kısıtladığı için saldırı harekâtlarını zorlaştırması hem de Rusya'nın Alman Doğu Cephesi'ne öncelik vermek zorunda kalmasına bağlıdır. Bölgede savaşın Osmanlı topraklarında cereyan etmesi, buradaki saldırı girişimlerini demiryolundan uzak ilkel lojistik hatlar sayesinde kısıtlayarak, Osmanlı başkentinin mesafesinin derinliğini korumuştu. ${ }^{16}$

16 Buna benzer bir olay 1941'de Almanya Sovyetler Birliği'ne saldırdığında da gerçekleşmiştir. 
Rusya, Ermenileri belki de bu sorunu aşabilmek açısından cephedeki harekâtların askeri-siyasi bir uzantısı olarak gayri nizami harp şartlarında kullanmıştı. Nitekim Osmanlı jeopolitiğinin belkemiği olan Anadolu coğrafyasını Akdeniz-Karadeniz ekseninde bölünmesi, Rusya'nın Doğu Anadolu içlerine kadar sokulmasının yanında Ermenilerin Osmanlı cephe gerisini inceltmesiyle mümkün olabilirdi. Bu da Ortadoğu'daki cephelerde savaşan Osmanlı ordularının irtibatını kesebilirdi. Tehcir ile bu engellendiyse de Ermenilerin faaliyetleri Kafkasya, İran, Afganistan ve Orta Asya'da umulan Osmanlı etkisinin potansiyeline engel olmuştu.

Bütün bu olaylar birleştirildiğinde ve diğer cephelere potansiyel etkileri düşünüldüğünde, Anadolu'nun Osmanlı jeopolitiğinin belkemiği olduğunu göstermektedir. Yani Osmanlı gücünün ikiye bölünmesi ancak Anadolu'dan Ortadoğu'ya olan ikmal yollarının kesilmesiyle, yani Doğu Anadolu'dan İskenderun Körfezi'ne ulaşılmasıyla mümkündü. Bu açıdan Kafkas Cephesi'nin olumlu ya da olumsuz yönde gelişmesi, Osmanlı İmparatorluğu açısından hayati öneme sahipti.

\section{Sina ve Filistin Cepheleri}

Sina Cephesi, Kanal Harekâtı'nın girişildiği ve kanalın tehdit altında tutulduğu 1915-1916 yıllarında Osmanlı'nın Akdeniz'deki ileri harekât hattını teşkil etmiştir. İngiliz ticaretinin \% 75 kadarı Süveyş Kanalı ve Cebelitarık Boğazı'ndan geçiyordu. ${ }^{17}$ İngiliz Donanması'nın asimetrik üstünlüğü sayesinde Osmanlı Donanması'nın Doğu Akdeniz'de hâkimiyetinden bahsedilemezdi. Bunun üzerine kanalı hedef alan Osmanlı kuvvetleri 208 km'lik bir yürüyüşle Sina Çölü'nü geçerek, üç duba köprüden Süveyş Kanalı'nın batısına çıkmayı denemişlerdi. İsmailiye alındığında, Mısır'da İngilizlere karşı bir isyan çıkarılacaktı. ${ }^{18}$

Harekât taktik açıdan başarılı olmamakla birlikte, stratejik açıdan Almanya için başarılı, Osmanlı için başarısız olarak görülebilir. Bunun nedeni Batı Cephesi'ni hafifletmek isteyen Almanya'nın İngiliz tümenlerinin önemli bir bölümünü Mısır'da bulundurmasını istemesiydi. Ne var ki, stratejik ortaklığa girmesine rağmen, Osmanlı'nın Almanya ile çıkarları burada farklılaşmış, hatta Mısır'daki yığılma kendisine yönelik riski artırdığı için Osmanlı'nın çıkarları Almanya ile çatışmıştır da diyebiliriz. Nitekim teknik açıdan Kanal Harekâtı muazzam sayıda İngiliz askerinin bölgede kalarak, öncelikle kanalın savunması ve ardından da Sina'da ilerlemesi açısından derin bir tesir yapmıştı. ${ }^{19}$ Nite-

Alman motorlu taşıtlarının hızlı ve esnek hareketlerinin Rusya coğrafyasındaki yolların ilkelliği sayesinde kısıtlanması, harekâtın stratejik başarıya ulaşamamasında önemli bir faktör olmuştur.

17 Ian Westwell, The Complete Mlustrated History of World War I, Lorenz Books, London 2008, ss. 104-158.

18 Martin Gilbert, First World War, Henry Holt, New York 1994, s. 128.

19 Jon E. Lewis, The Mammoth Book of Modern Battles, Constable \& Robinson Press, London 2009, s.57.

Akademik Bakış 49 Cilt 8 Sayı 15 Kış 2014 
kim ilk harekâtta yoğun kıyı desteğine sahip, 70.000 olan savunma gücünün 1916 başlarında $400.000^{\prime}$ e çıkması ${ }^{20}$ da Alman stratejisinin başarısını ortaya koymaktadır. ${ }^{21}$

İngilizler açısından Sina ve Filistin cephelerinin stratejik derinliği oldukça fazlaydı ve buradan İstanbul'a erişmek son derece zor görünüyordu. Bu güzergâh üzerinde savunma açısından Osmanlılara sayısız savunma hattı sunuyordu. Sadece Irak ve Rusların Doğu Anadolu cepheleriyle bağlantı kurulmasıyla Osmanlı Ordusu'nu sarsacak bir etki yapılabilirdi. Nitekim bu üç cephe birleşmeden Anadolu'nun coğrafyasını İstanbul yönünde aşacak kalabalığın oluşması pek mümkün görünmemektedir.

Lojistik hatların Sina' da ağırlıkla ilkel olması, Filistin'de ise bir tek Hicaz Demiryolu ile besleniyor olması, hem İngiliz hem de Osmanlı orduları için dezavantajdı. Ancak Osmanlılar savunmada oldukları için lojistik ihtiyaçlarında harekâtlara bağlı esneklikleri daha kolay geçiştirebilirlerdi. İngilizlerin deniz yoluyla sıçrama yapması mümkün görünse de çok yakın geçmişte İtalyanların Libya'daki taktik başarılarının sadece kıyılarda sıkışması gibi bir örnek üzerine yeterince düşünmüş olabilirler. Nitekim Filistin'e doğru İngiliz ilerlemeleri karadan yapılırken, deniz desteğinin lojistik sağlama ile kısıtlanması bu şekilde açılanabilir.

Filistin Cephesi'ndeki kesin İngiliz zaferi Megiddo Muharebesi'nde, 1918 Eylül'ü gibi geç bir tarihe kadar gerçekleşmemiştir. İngilizlerin Sina ve Filistin cepheleri boyunca savunmadan saldırıya geçip ilerlemelerinin Suriye'nin kuzeyine ulaşması dört yıla yakın bir zamanı bulmuştur. Dolayısıyla Osmanlı coğrafyasıyla savaşın genişlemesinde Sina ve Filistin cephelerindeki mücadele sayesinde Britanya İmparatorluğu'nu savaş boyunca olumsuz etkilediği ortaya çıkmaktadır.

\section{Irak Cephesi}

Akademik
Irak Cephesi'nin stratejik derinliğini incelersek, Filistin'e göre İstanbul'a ulaşımın buradan daha zor olduğunu görürüz. Bunun nedeni hem Kuzey Irak'ın dağlık oluşu hem de Halep-Bağdat Demiryolu'nun bitirilememesiydi. Bununla birlikte, Osmanlı İmparatorluğu savaşa girdiğinde İngilizlerin ilk bastıkları Osmanlı toprağı Basra olmuştu. İngilizlerin Irak'ta giriştikleri bu serüvenin ardından 1915'te hız kazanan Bağdat'a ilerlemesi, Osmanlı Ordusu'nun Selman-1 Pak'taki sert direnişi sonucu buradan çekilmek zorunda kalan İngiliz birliklerinin Kut-ül Amare'de kuşatılması ve 29 Nisan 1916'da teslim olmasıyla sekteye uğramıştı. Osmanlı Ordusu Kut Harekâtı boyunca manevra üstünlüğünü elinde tutarken, hem savunma hem de saldırıda başarılı olmuşr ve geçmişi Alesia'ya ulaşan bir de askeri tarih dersi vermişti.

20 A.g.e., s. 58.

21 Savunma gücünün bu kadar yükselmesinin bir başka nedeni de Mısır'ın 1915 Nisan'ında başlatılan Gelibolu Harekâtı için ileri toplanma üssü olmasıdır. 
Şüphesiz, İngilizler savaşın Irak Cephesi'nde de uzayacağını ve Filistin ile birlikte Irak gibi stratejik derinliğe sahip ikinci bir cephede daha savaşı sürdürmek zorunda olduklarını fark etmişlerdi. Ancak İngilizlerin Osmanlı'ya karşı stratejik sonucun alınması kadar önemli olan bir mevzu da Ortadoğu'nun petrol rezervlerinin kontrolüydü. Bunun için Irak'a daha fazla birlik ayırmaları gerekecekti. Nitekim İngiliz Tümgeneral Charles Townshend'in 11.000 askerle yaptığı ilerleme Osmanlı Ordusu tarafından yok edildikten sonra, 1916'da İngiliz Korgeneral Frederick Maude'nin yeniden ilerlemesi iki koldan ve 166.000 askerle yapılmıştır. ${ }^{22}$

\section{Diğer Cepheler Ve Sınır Ötesi Faaliyetler}

Osmanlı İmparatorluğu Avrupa'nın güneydoğu kanadını çeviren coğrafi hâkimiyeti ve aynı zamanda batıya yönelmiş Müslüman bir ülke olması sayesinde, hem kendi hem de Almanların Asya-Afrika ekseninde özel harekât idare merkezi konumundaydı. Ünlü askeri tarihçi Hans Delbrück 1908'de Bosna'daki krizin patlak vermesinden kırk gün önce, savaşın Fas'ta ya da Türkiye'de patlak vermesi durumunda ne kadar yayılabileceğinin hesaplanamayacağını söylemiştir. İran, Hindistan, Mısır ve Süveyş'i savunmak için İngiltere de savaşa sürüklenebilirdi. Eğer Almanya ve Avusturya padişahı takviye ederse, Şam-Mekke Demiryolu'ndan büyük bir Türk ordusu Suriye'den geçirebilirdi. ${ }^{23}$ Delbrück'ün bu tutarlı saptaması, Avrupa ülkeleri arasındaki büyük bir savaşa Müslüman halkın katılımının belirsizliğini işaret ettiği şeklinde yorumlanabilir. Nitekim Almanlar bu belirsizliği Osmanlı’yı kendi saflarına çekerek kullanmak istemişlerse de sonuç alamamışlardır.

Osmanlı güçlerinin savaştığı diğer cepheler ve sınır ötesi faaliyetlerin hedefinde İngiliz sömürgeleri olduğunu görüyoruz. Hicaz, Asir ve Yemen cepheleri Osmanlı güçlerinin bölünmesini getirmiş, buna karşı Süveyş-KızıldenizHint Okyanusu rotasındaki lojistik istasyonların elde edilmesi hedefinde bir gelişme sağlanamamıştı. Aden'deki harekât iki Hint tugayını bir süre oyalamaktan öteye gitmemişti. ${ }^{24}$

Padişah 1914 Kasım'ında halife sıfatıyla Cihad-1 Mukaddes ilan ederek bütün dünya Müslümanlarına çağrıda bulunmuştu. Hindistan başta olmak üzere, Afganistan, Mısır, Türkistan, Mağrip, Doğu ve Batı Afrika Müslümanlarının bu çağrıya karşı ne yapacakları önemliydi. ${ }^{25}$ Çağrının etkisi, İtilaf Devletlerinin hepsi açısından risk ve tehdit arasında oldukça farklı seviyelerde karşı-

22 Ian Westwell, The Complete Illustrated History of World War I, Lorenz Books, London 2008, ss. 104-105.

23 Hans Delbrück, (ed. Arden Bucholz), Delbrück's Modern Military History, University of Nebraska Press, Lincoln 1997, s.86.

24 Philip J. Haynthornthwaite, The World War One Source Book, Arms and Armour Press, London 1994, s. 123

25 Pierre Renouvin, 1. Dünya Savaşı 1914-1918, (çev: Adnan Cemgil), Altın Kitaplar, 3. Baskı, İstanbul 1982, s.542. 
lık bulabilirdi. Çünkü İngiliz, Rus ve Fransız sömürgelerinin hepsinde de çok sayıda Müslüman yaşıyordu. Dolayısıyla Almanlar stratejik seviyede Osmanlı jeopolitiğini doğru okumuşlardı. Ancak bu çağrının gereken etkiyi yapmaktan çok uzak kalması, bunun için Osmanlı jeopolitiğinin yeterli olmadığını ve sömürgelerdeki yerel politikalara da bağlı olduğunu göstermiştir.

Afganistan'da savaşın başında İngilizlerin Emir Habibullah Han'a bağımsızlık sözü karşılığında tarafsızlığını ilan etmesini istemesi anlamlıdır. Bu sayede Afganistan'a gönderilen Alman ve Türk heyetler buraya sızmakta başarılı olamamışlardı. ${ }^{26}$ En önemli sızma hedefi ise Hindistan olup, coğrafi uzaklık Osmanlı'nın buraya ulaşmasına engeldi. Hindistan zaten kolay yönetilen bir ülke değildi. İngilizlerin buradaki Müslüman halkı kendi lehine etkilemesi, dış politikasında göz ardı edilmeyen bir husustu. Nitekim Hindistan Genel Valisi Lord Charles Hardinge Çanakkale'de zaferin İran ve Afganistan'daki Alman yanlısı Müslümanlar üzerine kuvvetli bir etki yaratacağına inanıyordu. ${ }^{27}$ Hatta Çanakkale Deniz Harekâtı'nın başarısızlığına rağmen, ertesi gün Britanya Savaş Konseyi Osmanlı'ya karşı kazanılacak zaferin meyvelerini düşünürken, Hindistan'daki 60 milyon Müslüman üzerine yapacağı iyi tesir açısından İngiliz himayesindeki Arabistan, Suriye ve Mezopotamya'yı tartışıyorlardı. ${ }^{28} \mathrm{Bu}$ arada İngilizler Hindistan'daki Müslümanlarla ilişkilerinde savaş boyunca daha dikkatli davrandilar.

Padişahın çağrısının etkisi Libya ve Sudan gibi bazı bölgelerde küçük çapta etkisini göstermişti. Ancak bu çağrıyla beklenen stratejik sonuca ilişkin bir emare görünmüyordu. Hicaz'da ise İngiliz istihbarat çalışmalarıyla ortaya çıkan Mekke Şerifi Hüseyin'in Arap İsyanı, padişahın çağrısını dengelemekten ileri gitmiş, Filistin'deki harekâtın kaderini de etkilemişti. Fahreddin Paşa'nın kuşatma altında ve mütareke sonrasına da taşan Medine Savunması ise İngiliz ve Arap birliklerini oyalamaktan ziyade, itibarı artıran bir kahramanlık destanı olmuştu.

Akademik

Bu arada Alman Doğu Afrikası'nda çevrelenmiş ama teslim olmadan çok sayıda İngiliz ve Fransız birliğini etkili bir gerilla savaşıyla oyalamayı başaran Albay Paul von Lettow-Vorbeck'in koloni birliklerine lojistik destek sağlamak için Bulgaristan ve Osmanlı'yı üs olarak kullanma ihtiyacı doğmuştu. Zeppelin L.59'un 21-25 Kasım 1917'de gerçekleştirdiği, ancak çeşitli nedenlerden ötürü başarıya ulaşmayan seferinden ${ }^{29}$ sonra bu düşünceden vazgeçilmesine rağmen, Merkez Güçlerin Doğu Afrika'daki Alman direnişine en yakın ikmal bölgesinin Osmanlı toprakları olduğu göze çarpmıştı. Mısır Osmanlı'da olsaydı,

26 Philip J. Haynthornthwaite, The World War One Source Book, Arms and Armour Press, London 1994, s. 123.

27 Martin Gilbert, First World War, Henry Holt, New York 1994, s. 135.

28 A.g.e., ss.136-137.

29 Arthur Banks, A Military Atlas of the First World War, Leo Cooper, Barnsley 1998, s.285. 
buradaki Alman birliklerine yapılacak yardımlar sayesinde Doğu Afrika'daki Alman kolonisi canlı tutulabilirdi.

\section{Osmanlı Coğrafyasının Etkilediği Askeri-Siyasi Davranışların Analizi}

Osmanlı coğrafyasının en çok hizmet ettiği ülkenin Almanya olduğu açıkça görülmektedir. Nitekim Almanlar da savaşın yayılması adına Osmanlı topraklarını kullanmak için ellerinden geleni yapmış, Yavuz gibi önemli bir savaş kruvazörünü bağışlamayı esirgememişlerdir. Ne de olsa Almanya'nın Batı ve Doğu cephelerinde rahatlaması, Müttefiklerin Osmanlı'nın Irak ve Filistin gibi Avrupa'daki cephelerden daha fazla stratejik derinliğe sahip cephelerinin üstesinden gelebilmek için çok daha fazla birlik, deniz gücü ve lojistik destek ayırmasına bağlıydı. Almanlar Osmanlı coğrafyasının bu önemini biliyorlardı ve bir ittifak stratejisi uygulayarak, savaşı genişletmek amacıyla kullanmışlardı. Almanlar savaş boyunca Osmanlı cephelerine sadece 50.000 asker (bir kolordu kuvveti) gönderirken, Türkler imkânlarının çok üstünde çaba göstererek İtilaf Devletleri'nin güçlerinin ve kaynaklarının büyük bölümünü üzerlerine çekmişlerdi. ${ }^{30}$

19. yüzyılın sonlarına doğru Alman İmparatorluğu ve Osmanlı İmparatorluğu arasında başlayan yakınlaşma, Almanya açısından Almanya'nın Ortadoğu'da İngilizler ile çatışan çıkarlarının bir uzantısı niteliğindeydi. 1907'de Britanya ve Rusya İran ve Afganistan'da aralarında uzun süredir devam eden ihtilafı gidermeye yönelik bir anlaşma imzalamışlardı ve bu da Almanya'nın ileride çevreleneceğinin bir kanıtı niteliğindeydi. Almanya 1899'dan itibaren İstanbul'u Avrupa'dan Asya'ya geçiş noktası olarak kullanacağı Berlin-Bağdat demiryolu hattı projesiyle doğu emellerini belli etmişti. ${ }^{31}$

Berlin-Bağdat demiryolu Almanya'nın Osmanlı jeopolitiğine sahip çımaya çalışmasının simgesi olmuştur, diyebiliriz. Hatta İngilizlerin Almanya'nın Ortadoğu'yu demiryolu ağıyla İstanbul'a ve Berlin'e bağlaması girişimini bölgesel çıkarlarına yönelik artan bir riskten ziyade, küresel hâkimiyeti hedefleyen bir tehdit olarak gördügüunü de söyleyebiliriz. Nitekim proje Gazze ve Kızıldeniz kıyısındaki liman kenti Akabe boyunca ikinci bir hatta sahipti ve bu sayede Süveyş'e yaklaşıyordu. İngiltere Almanların Akabe limanında bir terminusa ${ }^{32}$ sahip olmalarının verdiği endişeyle 1906'da Sina'nın doğusundaki verimsiz toprakları Mısır topraklarını ilhak etmişti. ${ }^{33}$ Almanların yaklaşık 3200 km uzunluğunda bir demiryolu hattı girişimiyle Avrupa, Anadolu ve Arap vilayetlerini rahatça geçebilmeleri düşüncesi, İngilizlerin İran Körfezi ve Hint Okyanus'undaki çıkarlarını da tehdit ediyordu. ${ }^{34}$ Ancak Balkan Savaşları Osmanlı'nın Avus-

30 Edward J. Erickson, I. Dünya Savaşı́nda Osmanlı, (çev: Sare Levin Atalay), TímAŞ, İstanbul 2011, s.30.

31 Martin Gilbert, First World War, Henry Holt, New York 1994, s.6.

32 Demiryollarında son durak niteliğindeki gar.

33 A.g.e., ss.6-7.

34 A.g.e., s.7. 
turya üzerinden Almanya ile bağlantısını kestiği için Almanya'nın Osmanlı jeopolitiğini kullanmasını savaş zamanına bırakmıştı.

Osmanlı'nın savaşa hazır olmadan girişi, Alman politikasının kurbanı olduğunu göstermektedir. Nitekim Çanakkale Boğazı'nın savunmasının yetersizliği ve Irak'ta gerektiği şekilde garnizon kuramaması ${ }^{35}$ gibi stratejik sorunların yanında demiryollarının yetersizliği, savaş endüstrisine sahip olmaması ve tümenlerin kamyonlardan yoksun oluşu gibi lojistik sorunlar da mevcuttu. Büyük güçlerin aksine Osmanlı'nın bir ani taarruz planı da yoktu. ${ }^{36}$ Zaten Almanya'nın Osmanlı'yı savunma ağırlıklı savaş için İngiliz birliklerinin üstüne çekmesi için kullanma istediği buradan da anlaşılabilir. Ne de olsa Osmanlı İmparatorluğu'ndaki demiryolu hatları saldırı harekâtına değil, savunma harekâtına elverişliydi. Sadece batı sınırına kadar demiryolu gidiyordu. Doğu ve güneyde ise terminuslar sınırın oldukça derinlerinde bulunuyorlardı. Dolayısıyla Osmanlılar lojistik faaliyetlerini ayarlarken, bunu Balkanlar haricinde ancak savunma savaşında verimli kullanabilirlerdi. Nitekim Sarıkamış Muharebesi'nde bu eksiklik açıkça göze çarpmıştır.

İngilizlerin Osmanlı jeopolitiğinin Birinci Dünya Savaşı' açısından rolünü ise ancak savaşın sonunda anladıklarını söyleyebiliriz. 1918'e gelindiğinde yeni Kraliyet Genelkurmay Başkanı General Henry Wilson'un tavsiyesiyle Başbakan Lloyd George Almanya'nın yenilgisi için öncelikle Fransa'da savunmada kalınması ve Suriye'de Osmanlı'ya hamle yapılmasıyla Merkez Güçler'in dağılabileceği düşüncesini kabul etti. ${ }^{37}$ Orgeneral Edmund Allenby'nin Filistin ve Suriye'deki galibiyetlerinin ardından Halep'in kuzeyinde cephe tekrar kurulmuştu ve gerisinde savunması daha da olanaklı Toroslar uzanıyordu. Ancak Osmanlı'nın stratejik derinlik açısından tek sorun yaşayabileceği cephe Selanik Cephesiydi. Bu sırada Selanik Cephesi de çöküp, General George Milne'nin ordusu İstanbul'a doğru ilerlemeye başlayınca, burada savunma kuvveti artık Akademik son derece az olan hükümet de ateşkes yapmanın yollarını aramaya başlamıştı. ${ }^{38}$ Wilson'un planı tutmuş, Osmanlı'nın savaştan çekilmesinin hemen ardından artık tamamen çevrelenmiş olan Almanya da onu izlemişti.

Almanların Osmanlı coğrafyasını kullanarak savaşı genişletme stratejisi Almanları Avrupa'daki sıkışmışlıktan kurtaran en verimli girişim olmuştu. Dolayısıyla kısa vadede Almanların lehineydi. Ancak bu akılcı strateji Osmanlı İmparatorluğu'nun sonunu hazırlamış, bu da 19. yüzyılda Kuzey Afrika'ya yerleşen İngiliz ve Fransız etkisinin 20. yüzyılın ilk yarısında Ortadoğu'ya sıç-

35 Edward J. Erickson, I. Dünya Savaşı'nda Osmanlı, (çev: Sare Levin Atalay), TiMAŞ, İstanbul 2011, s.29.

36 A.g.e., s.26.

37 Hans Delbrück, (ed. Arden Bucholz), Delbrück's Modern Military History, University of Nebraska Press, Lincoln 1997, s.183.

38 A.g.e., s.211 
ramasına neden olmuştu. Dolayısıyla Almanya bu stratejinin bedelini uzun vadede ödemiştir. Bu vade İkinci Dünya Savaşı'nda 13 Mayıs 1943 tarihinde Kuzey Afrika Cephesi'nin kapanmasına kadar sürmüş, bundan sonra Almanlar Ortadoğu'ya yönelik siyasi ya da askeri bir girişimde bulunmaya coğrafi açıdan uzak kalmışlardır.

Almanya'nın Osmanlı’nın stratejik derinliğini çok yönlü kullanarak kısa vadede savaşı yayması Avrupa'daki Alman harekâtları için genel bir fırsat niteliğinde değerlendirilmelidir. Almanlar özellikle İngiliz koloni birliklerinin çoğunu Avrupa'dan uzakta ve ağırlıkla Osmanlı Ordusu'nun kuvvetiyle kırmaya çalışmışlardı. Böylece Avrupa'ya nakledilmek suretiyle Batı Cephesi'ne, Kuzey İtalya'ya ya da Balkanlar'a kaydırılması beklenen kolonilerdeki çok sayıda İngiliz tümeninin uzaktan karşılanması sağlanmıştır. Bu açıdan bakıldığında Osmanlı İmparatorluğu Almanya'nın bir ileri karakolu rolüne sahipti.

\section{Sonuç}

Alman destekli büyük çaplı erken Osmanlı başarıları Çanakkale ve Gelibolu cephelerinde ve Kut'ta hem saygınlık hem de İngiliz kayıplarını artırma açısından oldukça başarılı olmuştu. Filistin'deki muharebeler ise Gazze'de uzun süren bir beraberlik halinden sonra, ancak savaşın son döneminde kırılabilmiştir. Bu arada Kanal Harekâtı'nda oynadığı kumarı kaybetmiş olsa da Osmanlı'nın Süveyş'i tehdit etmesi, İngilizlerin bölgedeki etkinliğini artırma ihtiyacını doğurduğu için Almanlar açısından oldukça verimli bir gelişme olarak görülebilir. Kanal'ın tehdidi ve Kut birlikte ele alındığında, İngilizlerin Ortadoğu'da Osmanlı'ya karşı tek bir cephede saldırmasının yetersizliği ortaya çıkmaktadır. İngilizler bu yüzden Ortadoğu harekâtını Irak ve Filistin cepheleri olarak iki koldan yürütmüş, bu da İngiliz Ordusu'nun bölgeye daha fazla tümen, deniz gücü ve lojistik destek ayırmasına yol açmıştır. Buna rağmen Osmanlı Ordusu 1917 Kasım'ında Üçüncü Gazze Muharebesi'nde yenilene kadar İngiliz kuvvetlerini karşılama gücüne sahipti.

Sonuç olarak Osmanlı'nın Alman stratejisine yaptığı katkı, ne Alman İmparatorluğu'nun ne de Osmanlı İmparatorluğu'nun dağılmasını engelleyememişti. Ancak Osmanlı'nın coğrafyası sayesinde savaşta beklenenden uzun dayanması, Rus İmparatorluğu'nun çökmesine yol açmıştı. Dolayısıyla Almanların bu stratejisi 20. yüzyılın iki büyük gücünden birisinin oluşmasına zemin hazırlamıştır. İlginç olan bir nokta, Alman stratejisinin sadece İngilizleri Ortadoğu'ya sokmakla kalmaması, aynı zamanda Almanya'nın başına gelecek en büyük felakete neden olan Sovyetler Birliği'ni de yaratmasıdır. Zaten İkinci Dünya Savaşı'ndaki harekâtlara bakacak olursak, Almanların 1942'de Ortadoğu ve Kafkas petrollerine ulaşma düşüncelerinin Birinci Dünya Savaşı'ndaki Osmanlı jeopolitiğiyle ilişkisini de açıkça görebiliriz.

Akademik Bakış 55 Cilt 8 Sayı 15 Kış 2014 


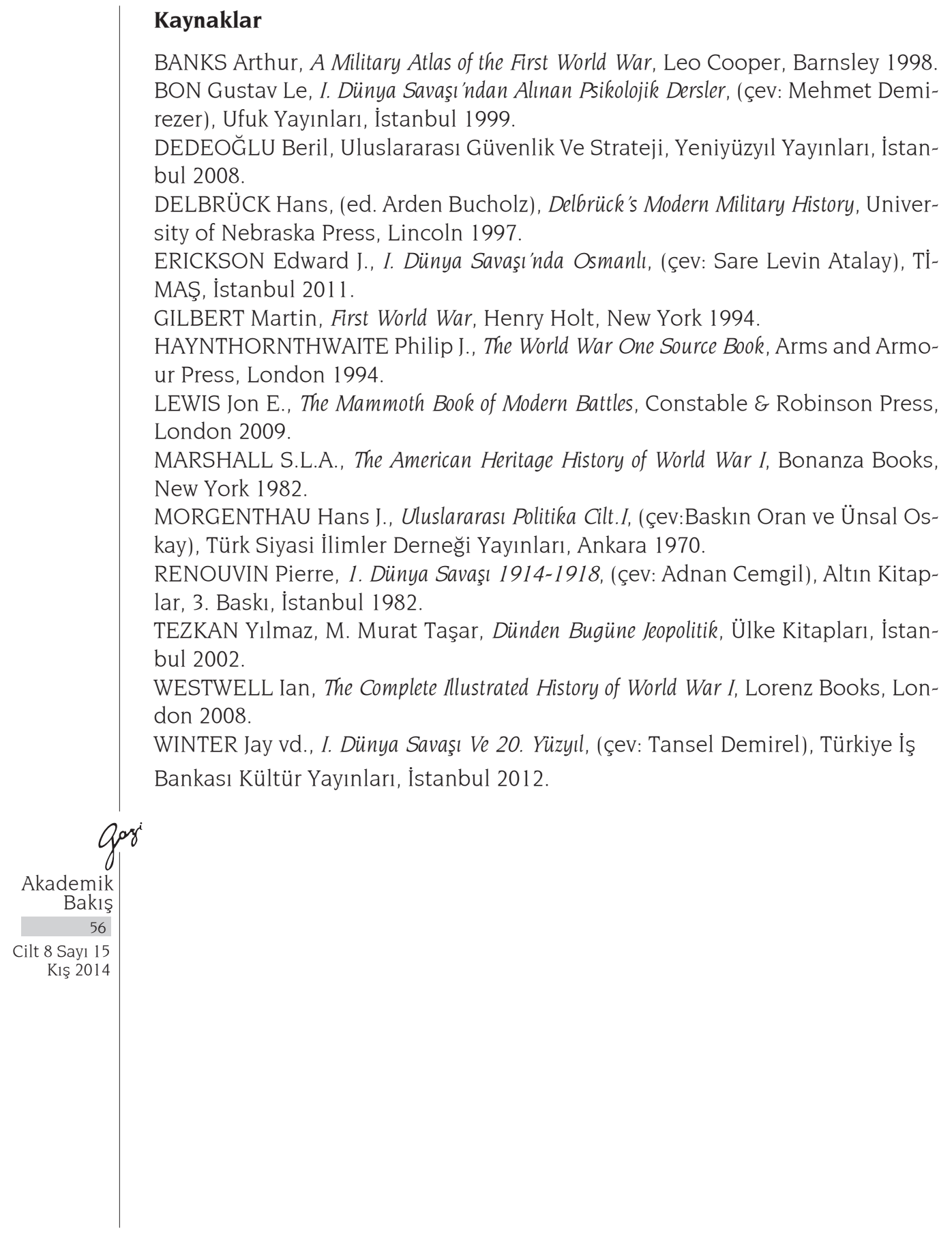

